Journal Wetenskap Health

\title{
Culture Analysis of Patient Safety Incident Report of Nurses in Inventories of Sawerigading Regional Public Hospitals (RSUD), Palopo
}

\author{
Try Ayu Patmawati ${ }^{1}$, Nur Asphina R. Djano ${ }^{2}$ \\ *Corresponding: tryayupatma@gmail.com \\ ${ }^{1}$ Nursing Study Program, Faculty of Health, Mega Buana Palopo University, Indonesia \\ ${ }^{2}$ Public Health Study Program, Faculty of Health, Mega Buana Palopo University, Indonesia
}

\begin{abstract}
This study aims to analyze the incidents reporting culture of nurses in the inpatient room. The research design used in this study was descriptive analytic with a cross sectional approach. The population in this study were nurses at Sawerigading Palopo Hospital with a sample of this study as many as 140 nurses, sampling using purposive sampling technique. The instrument used was the IRCQ (Incident Reporting Culture Questionnaire). It was found that from 140 respondents there were 77 respondents (55\%) who showed a negative response to the culture of reporting incidents and showed a positive response there were 63 people (45\%). Based on the four incident reporting factors, the factor that received the greatest negative response was the "collegial atmosphere due to discomfort and punishment" with a total of 119 respondents $(85 \%)$. The culture of reporting incidents in the inpatient room of the Sawerigading Palopo public hospital must be improved and minimize any concerns from nurses regarding punishment and fear.
\end{abstract}

Keywords: Incident Report, Patient Safety, Nurses

\section{Introduction}

Incident reporting is an important first step to improve patient safety (Reed et al., 2013). However, most hospital incident reporting systems rely on voluntary reporting by staff (Braithwaite et al., 2010; Henriksen et al., 2005; Kousgaard \& Joensen, 2012).

Voluntary incident reporting systems are one approach to improving patient safety, as evidenced by their inclusion in many hospital accreditation programs. Canadian accreditation now has voluntary incident reporting as one of its Required Organizational Practices (The Joint Commission, 2013), and the Australian Commission on Safety and Quality in Health Care has a standard entitled "Governance for Safety and Quality in Healthcare Organizations," in where incident reporting is a core requirement (Acreditation, 2014) while in Indonesia the Ministry of Health of the Republic of Indonesia established a National Patient Safety Committee to carry out five functions including developing and managing an incident reporting system, analysis and preparation of patient safety recommendations. KNKP is one of the external reporting places for all KPRS (Hospital Patient Safety) Teams in Indonesia (Ministry of Health, 2017)

In hospitals, the main challenge to reporting incidents related to patient safety is the fear of being blamed and punished (Brunsveld-reinders et al., 2016; Wagner et al., 2013). Some studies suggest that voluntary incident reporting systems have also been described as a source of frustration, failing to produce the expected benefits. Its effectiveness is diminished due to barriers to voluntary incident reporting, some of which are related to concerns about the impact on health care professionals (Hughes, 2008; Noble, 2010; Shojania, 2008). So that one of the main problems in operating an incident reporting system is how to facilitate incident reporting (Evans et al., 2006). 
Reporting patient safety incidents should become a culture in the hospital so that incidents can be analyzed and can be a lesson to find the root of the problem and find solutions for improvement and there is no culture of blame for whistleblowers, therefore the hospital must create a fair and open culture so that staff dare to report and incident handling is carried out systematically, including for nurses (Ministry of Health, 2017).

Several studies have discussed surveys of patient safety culture both in Indonesia and several foreign countries (Abdi et al., 2015; Amirullah et al., 2014; Pujilestari et al., 2014; Rachmawati, 2011), so that the urgency of this research is still a little. which discusses the culture of reporting patient safety incidents abroad and even in Indonesia there has been no research related to this using instruments with patient safety incident reporting content. Therefore, the aim of this study was to analyze the culture of reporting patient safety incidents to nurses at the Sawerigading Palopo Hospital.

\section{Methods}

The research design used in this research is descriptive analytic with a cross sectional approach to analyze the culture of reporting incidents of nurses at Sawerigading Palopo Hospital. The population in this study were nurses at Sawerigading Palopo Hospital with a sample of this study as many as 140 nurses, sampling using purposive sampling technique. The instrument used was the Incident Reporting Culture Questionnaire.

\section{Results and Discussion}

In table 1, it is found that the average age of the respondents is 34.24 , consisting of 12 men (8.6\%) and 128 women (91.4\%), in addition to 140 respondents, 42 (30\%) of whom are educated Ners, S1 as many as 84 people (60\%) and D3 Nursing as many as 14 people (10\%). Table 1 also shows that most of the respondents have worked more than 5 years. In table 1 , it is found that out of 140 respondents, 23 people (16.4\%) were nurses in the orchid / surgical treatment room, 19 people (13.6\%) were nurses in the fir room, 8 people $(5.7 \%)$ were nurses in the dahlia room / child care, 28 people $(20 \%)$ were nurses in the edelweiss room (internal care), 21 people (15\%) were nurses in the orchid room, 19 people $(13.6 \%)$ were nurses in the geranium room, 22 people $(15.7 \%)$ were nurses in the ICU.

In table 2, it is found that out of 140 respondents, there were 77 respondents (55\%) who showed a negative response to the culture of reporting incidents and showed a positive response, there were 63 people $(45 \%)$.

In table 4, it is found that from the four factors / subscale of the incident reporting culture, the results are that in the "application of learning from mistakes" there were 21 respondents (15\%) who showed negative responses while those who showed positive responses were 119 people (85\%) "Readiness to provide feedback on incident reports" there were 26 respondents $(18.6 \%)$ who showed negative responses while those who showed positive responses were 115 people $(81.4 \%)$, on the factor "collegial atmosphere due to discomfort and punishment" contained 119 respondents $(85 \%)$ who showed a negative response while those who showed a positive response were 21 people (15\%), and on the factor "incident management: confidential and based on system" there were 50 respondents $(35.7 \%)$ who showed negative responses while those who showed a positive response of 90 people $(64.3 \%)$.

Based on the results of this study, it was found that the culture of incident reporting showed a negative response of $55 \%$ while a positive response of $45 \%$. The low positive response to reporting this incident is as in the results of research conducted (Adrini et al., 2015; Mandriani et al., 2019; Gunawan et al., 2015). Many factors caused this to be not optimal, some nurses also said they did not understand what incidents should be reported, in research (Hwang et al., 
2012) also stated that in addition to the role of managers in controlling reports, understanding and skills were very important factors. necessary for effective reporting of incidents (eg sentinel events and near misses). In addition, according to research (Najihah, 2018), there are still many health workers who ignore incident reporting because they feel that the incident can be handled alone and only report when an injury has occurred.

In addition, the nurse said that the fear of disrupting peer-to-peer relations was also the cause of reporting not being carried out and inadequate supervision was also a factor that needed to be improved in increasing incident reporting, this was also strengthened by (Adrini T et al., 2015; Prang \& Jelsness-Jørgensen, 2014).

This study uses the IRCQ instrument to take a deeper look at the culture of reporting patient safety incidents. The structure of the IRCQ instrument is a reflection of the cultural features of incident reporting with a human error approach. In the "application of learning from mistakes" factor there is a positive response of $85 \%$, the learning culture from these errors must be maintained as stated (Mahajan, 2010), incident reporting is learning opportunities for nurses (Waters et al., 2012) therefore a supportive learning environment is needed to stimulate increased reporting (Arabi et al., 2016).

On the factor of "readiness to provide feedback on incident reports", obtained a positive response of $81.4 \%$. The implementation of this feedback must be maintained so that it needs monitoring and evaluation from the hospital because according to research (Mandriani et al., 2019) without adequate feedback it will not encourage reports (Lederman et al., 2013).

Based on the results of the study, it was found that of the four factors, the factor that had the lowest positive response was the third factor, namely "collegial atmosphere due to discomfort and punishment" with a percentage of $15 \%$. Based on the data obtained, inpatient nurses answered that they worried that they would disturb the relationship between friends. In the hospital, the main challenge to report incidents related to patient safety is fear of being blamed and punished (Wagner et al., 2013). that the main obstacle in reporting incidents is the fear of being blamed (Carayon et al., 2014; El-jardali et al., 2011; Najjar et al., 2015; Suryanto $\&$ Febri, 2018). The hospital should pay attention not to there is another blaming response from both management and colleagues so that it is pushing ong health professionals, particularly nurses to report incidents, this is supported by (Howell et al., 2015) which suggests that an open environment and a reduced fear of punishment response increases incident reporting.

The "incident management: confidential and system-based" factor shows a positive response of 46 respondents $(64.3 \%)$, this positive response can be improved because according to research (Howell et al., 2015) also states that when a learning environment is created being responsive and confidential will increase staff engagement with disclosure of errors. Research (Elliott et al., 2014) also states that the development of a system for recording and reporting patient safety incidents must be done in an anonymous, confidential manner, and can be used simultaneously by multi-users.

\section{Conclusion}

Reporting incident reporting is useful for monitoring the prevention of errors in the delivery of health services. Therefore, an incident reporting culture must become a habit for health workers, especially nurses who are in inpatient rooms. The culture of reporting incidents at the Sawerigading Palopo public hospital, especially in the inpatient room, should be improved again and to minimize any concerns from nurses regarding punishment and fear. Therefore it is important for all boards of directors and management to monitor and evaluate the culture of incident reporting in order to improve patient safety 


\section{References}

Abdi, Z., Delgoshaei, B., Ravaghi, H., Abbasi, M., \& Heyrani, A. (2015). The culture of patient safety in an Iranian intensive care unit. Journal of Nursing Management, 333-345. https://doi.org/10.1111/jonm.12135

Acreditation, C. (2014). Required Organizational Practice Handbook. Canada.

Adrini T, M., Harijanto, T., \& Woro U, E. (2015). Faktor-faktor yang Mempengaruhi Rendahnya Pelaporan Insiden di Instalasi Farmasi RSUD Ngudi Waluyo Wlingi. Jurnal Kedokteran Brawijayak, 28(2), 214-220. https://doi.org/http://dx.doi.org/10.21776/ub.jkb.2015.028.02.17

Amirullah, N. A., Pasinringi, S. A., \& Kapalawi, I. (2014). Gambaran Budaya Keselamatan Pasien Di RSUD Syekh Yusuf Kabupaten Gowa. 1-16.

Arabi, Y. M., Owais, S. M., Al-Attas, K., Alamry, A., Alzahrani, K., Baig, B., ... Taher, S. (2016). Learning from defects using a comprehensive management system for incident reports in critical care. Anaesth Intensive Care, 210-220. https://doi.org/10.1177/0310057X1604400207

Braithwaite J, Westbrook MT, Travaglia JF, H. C. (2010). Cultural and associated enablers of, and barriers to, adverse incident reporting. Quality Safe Health Care, 19(3), 229-233.

Brunsveld-reinders, A. H., Arbous, M. S., Vos, R. DE, \& Jonge, E. DE. (2016). Incident and error reporting systems in intensive care: a systematic review of the literature. International Journal for Quality in Health Care, 28(December 2015), 2-13. https://doi.org/10.1093/intqhe/mzv100

Carayon, P., Wetterneck, T. B., Rivera-Rodriguez, A. J., Hundt, A. S., Hoonakker, P., Holden, R., \& Gurses, A. P. (2014). Human factors systems approach to healthcare quality and patient safety. Applied Ergonomics, 45(1). https://doi.org/https://doi.org/10.1016/j.apergo.2013.04.023

El-jardali, F., Dimassi, H., Jamal, D., Jaafar, M., \& Hemadeh, N. (2011). Predictors and outcomes of patient safety culture in hospitals. BMC Health Services Research, 11(45).

Elliott, P., Martin, D., \& Neville, D. (2014). Electronic Clinical Safety Reporting System : A Benefits Evaluation. JMIR Medical Infotmatics, 2(1). https://doi.org/10.2196/medinform.3316

Evans SM, Berry JG, Smith BJ, Esterman A, S. P., \& O’Shaughnessy J, et al. (2006). Attitudes and barriers to incident reporting: a collaborative hospital study. Qual Ity Safe Health Care, 15(1), 39-43.

Henriksen K, Battles JB, Marks ES, L. DI. (2005). Advances in patient safety: from research to implementation. Rockville (MD): Agency for Healthcare Research and Quality.

Howell, A., Burns, E. M., Bouras, G., Donaldson, L. J., Athanasiou, T., \& Darzi, A. (2015). Can Patient Safety Incident Reports Be Used to Compare Hospital Safety? Results from a Quantitative Analysis of the English National Reporting and Learning System Data. PLOS ONE Journal, 61, 1-15. https://doi.org/10.1371/journal.pone.0144107

Hughes RG, R. W. Z. (2008). Error reporting and disclosure. Patient Safety and Quality: An Evidence-Based Handbook for Nurses. Rockville,MD: Agency for Healthcare Research and Quality, U.S. Department OfHealth and Human Services, 39. 
Hwang, J., Lee, S., \& Park, H. (2012). Barriers to the Operation of Patient Safety Incident Reporting Systems in Korean General Hospitals. Healthcare Informatics Research, 18(4), 279-286. https://doi.org/10.4258/hir.2012.18.4.279

Kousgaard MB, Joensen AS, T. T. (2012). Reasons for not reporting patient safety incidents in general practice: a qualitative study. Scand Journal PrimaryHealth Care, 30(4), 199205.

Lederman, R., Dreyfus, S., Matchan, J., Hons, B. I. S., Knott, J. C., \& Milton, S. K. (2013). Electronic error-reporting systems : A case study into the impact on nurse reporting of medical errors. Nursing Outlook, 61(6), 417-426.e5. https://doi.org/10.1016/j.outlook.2013.04.008

Mahajan, R. (2010). Critical incident reporting and learning. British Journal of Anaesthesia, 105(1), 69-75. https://doi.org/10.1093/bja/aeq133

Mandriani, E., Yetti, H., \& Hardisman, H. (2019). Analisis Dimensi Budaya Keselamatan Pasien Oleh Petugas Kesehatan di RSUD dr Rasidin Padang Tahun 2018. Jurnal Kesehatan Andalas, 8(1), 131-137.

Najihah, N. (2018). Budaya Keselamatan Pasien dan Insiden Keselamatan Pasien di Rumah Sakit : Literature Review. Journal of Islamin Nursing, 3(1), 1-8.

Najjar, S., Nafouri, N., Vanhaecht, K., \& Euwema, M. (2015). The relationship between patient safety culture and adverse events : a study in palestinian hospitals. Safety in Health, 1(16), 1-9. https://doi.org/10.1186/s40886-015-0008-z

Noble D, P. P. (2010). Underreporting of patient safety incidents reduces health care's ability to quantify and accurately measure harm reduction. Journal Patient Safety, 6, 247250 .

Prang, I. W., \& Jelsness-Jørgensen, L.-P. (2014). Should I report? A qualitative study of barriers to incident reporting among nurses working in nursing homes. Geriatric Nursing, 35(6), 441-447. https://doi.org/10.1016/j.gerinurse.2014.07.003

Pujilestari, A., Maidin, A., \& Anggraeni, R. (2014). Budaya Keselamatan Pasien di Instalasi Rawat Inap RSUP Dr. Wahidin Sudirohusodo Kota Makassar. Jurnal Media Kesehatan Masyarakat Indonesia, 57-64.

Rachmawati, E. (2011). Model Pengukuran Budaya Keselamatan Pasien di RS Muhammadiyah-'Aisyiyah Tahun 2011. Proseding Penelitian Bidang Ilmu Eksakta, $11-34$.

Reed, S., Arnal, D., Frank, O., Hansen, J., Lester, O., Mikkelsen, K. L., ... Smith, A. F. (2013). National critical incident reporting systems relevant to anaesthesia : a European survey. 1-10. https://doi.org/10.1093/bja/aet406

Shojania, K. (2008). The frustrating case of incident-reporting systems. Qual Ity Safety Health Care, 17, 400-402.

Suryanto, S., \& Febri, D. T. (2018). Hubungan Budaya Keselamatan Pasien dengan Pelaporan Insiden Keselamatan Pasien oleh Perawat di Ruang Rawat Inap Rumah Sakit. Universitas Sumatera Utara.

The Joint Commission. (2013). Comprehensive Accreditation Manual For Hospital. 
Wagner, C., Smits, M., Sorra, J., \& Huang, C. C. (2013). Assessing patient safety culture in hospitals across countries. International Journal for Quality in Health Care, 25(3), 213-221.

Waters, N. F., Hall, W. A., Brown, H., Espezel, H., \& Palmer, L. (2012). Perceptions of Canadian labour and delivery nurses about incident reporting: A qualitative descriptive focus group study. International Journal of Nursing Studies, 49(7), 811821. https://doi.org/10.1016/j.ijnurstu.2012.01.009

Gunawan, G., Harijanto, H., \& Harijanto, T. (2015). Analisis Rendahnya Laporan Insiden Keselamatan Pasien di Rumah Sakit. Jurnal Kedokteran Brawijaya, 28(2), 206-213. 